\title{
Japanese Saris: Dress, Globalisation and Multiple Migrants
}

AMY JANE BARNES AND MALIKA KRAAMER

In this article, which is based on research in Leicester and Nairobi undertaken for the Cultural Olympiad exhibition Suits and Saris (New Walk Museum and Art Gallery, Leicester, 2012), we examine the phenomenon of Japanese saris - fashion-forward synthetic saris manufactured in Japan - and Leicester sari shop owners' role in their design and popularity in the 1970s and early 1980s. We use this previously untold story to explore transnational identities as manifested through cultures of dress. We investigate the transnational space in which these saris were produced and used, and we focus in particular on the multiple-migrant experiences of East African Asians, many of whom emigrated to Britain during the late 1960s and 1970s. We argue that the truly global phenomenon of Japanese saris would not have been possible without the transnational and multiple migrant nature of the South Asian diaspora.

\section{INTRODUCTION}

Some of the most pleasing consequences of developing a new exhibition are the unexpected stories that emerge from research. While working on the Cultural Olympiad exhibition Suits and Saris, on show at New Walk Museum and Art Gallery, in Leicester, between March and October 2012, we came across fascinating relationships between Britain (specifically Leicester), East Africa, India and Japan that were apparently absent from the scholarly record: the design, manufacture and consumption of synthetic saris from the 1960s to the 1980s (Figure 1). ${ }^{1}$ Suits and Saris explored global connections between South Asian and British historical and contemporary fashions and clothing traditions, including the role of East African Asians in these connections. Interaction was its focus. The exhibition did not attempt to present one big narrative, but rather a set of eye-opening, vibrant, dynamic stories based on research undertaken in Leicester and Nairobi. It was developed in collaboration with South Asian clothing businesses and a group of community and youth curators. Suits and Saris could, therefore, be thought of as an exhibition that enabled visitors to explore interrelated stories or, in more academic terms, as a postmodern exhibition featuring multiple voices. One of the 'stories' told in the exhibition and on which we focus in this article, was that of the so-called Japanese sari.

In this article we also aim to examine the global interactions of South Asian and British fashions, and British Asian styles dating to an earlier period than the typical focus of many prior studies: the transnational mid-twentieth century production, distribution and use of Japanese-made saris. We are particularly interested in examining the roles of multiple migrants in the multi-faceted global creation and consumption of these items, as this has been an aspect which is often, with the exception of 
Parminder Bhachu's work, not fully taken into consideration. ${ }^{2}$ We intend to demonstrate that the manufacture and consumption of Japanese saris have been shaped within a truly transnational space incorporating the UK, South Asia and East Africa, as well as other parts of the world with substantial South Asian diaspora communities. Japanese saris were of importance to consumers both within and outside South Asia, but were mainly produced in and exported from Japan to places where (multiple) migrants had settled during the nineteenth and twentieth centuries. We seek to understand the extent to which the multiple migrant character of some South Asian diasporas, such as Leicester's East African Asian communities, has impacted on the global phenomenon of Japanese saris. We argue that their production and popularity would not have occurred had it not been for the transnational and multimigrant nature of some key South Asian diaspora communities. In this article we aim to broaden the existing literature on transnational spaces and geographies of commodity culture, and in material aspects of transnational identities, by paying more attention to the particular migration routes of all those involved. Furthermore, a case study pertaining to the mid-twentieth century will develop understandings of British-Asian fashion that have so far focused predominantly on the late twentieth and early twentyfirst centuries.

[Figure 1 here: 1/4 page. Caption:

Japanese saris on display. Suits and Saris, New Walk Museum and Art Gallery, Leicester.

Photograph: (CLeicester Arts and Museum Service.]

\section{Dress, Globalisation AND Multiple Migrants}

Research on British Asian fashion has received substantial attention in recent years in exhibitions, research projects and publications, including the 2010 British Asian Style publication which developed out of the Arts and Humanities Research Council-funded research project, Fashioning Diaspora Space (a collaboration between Royal Holloway, University London and the Victoria and Albert Museum), the work of Bhachu on the role of British Asian women in the fashion economy, Claire Dwyer's analyses of transnational space through British-South Asian fashion, the work of Emma Tarlo on clothing and identities among South Asian consumers and on creative forms of Islamic fashion in Britain, and that of

Reina Lewis on faith-based 'modesty fashion'. ${ }^{3}$ However, the story of the Japanese sari is yet to be the subject of focused research, even though, as we will demonstrate in this article, it has a special place in the development of British Asian style. References to Japanese saris are scarce and scattered in scholarly literature; for example, both Mark-Anthony Falzon and Maritsa Poros mention them once in their studies on Sindhi migration to Britain and on Gujarati networks in New York and London respectively. ${ }^{4}$ Japanese saris are more often mentioned in contemporary fiction, most of the time in respect of 
inauspicious, everyday clothing, ${ }^{5}$ but occasionally in implied reference to sought-after, quality garments. ${ }^{6}$

The literature on dress, fashion and globalisation has also expanded exponentially in the last few years. ${ }^{7}$ The dichotomies between costume on the one hand and fashion on the other, and between socalled traditional dress outside the Western world and Western styles, have been problematized and deconstructed. Even the validity of the whole notion of 'Western dress' has, in the twenty-first century, begun to be questioned, but to date little research has been undertaken into the significance of specific migration routes on the clothing choices of multiple migrants. In an initial attempt to address this 'lack', this article develops our exhibition-focused research in Leicester and Nairobi, and builds on oral history recordings and engagement work undertaken with Leicester’s East African Asian community.

Our argument is indebted to the concept of transnational space as developed by Peter Jackson, Philip Crang and Claire Dwyer. They argue that transnational processes, including economic networks, political movements and cultural forms both reflect and produce transformations of social space. Space itself is 'constitutive of transnationality in all its different forms'. It is 'complex, multidimensional and multiply inhabited' and 'different transnational formations can, themselves, be distinguished by their different geographies, their particular spatialities’. ${ }^{8}$ The case of the Japanese sari parallels this argument. The transnational space in which Japanese saris have been produced, distributed and used is not restricted to the geographies inhabited by this particular 'global diaspora' of largely (multiple migrant) East African Asians - a group that in itself has a multiplicity of transnational experiences and relations but also incorporates places beyond these geographies, such as Japan. ${ }^{9}$

To set the context, the article begins with an introduction to the historical development of the sari, especially in respect of how it has been worn and by whom, and the methods and materials of its production. Following this is a more detailed discussion of the production and stylistic conventions of saris manufactured in Japan for export. The focus then turns to East African Asian migration to Britain in general and the development of the oldest locus of Asian Leicester, Belgrave Road, known internationally as 'the Golden Mile' after its many jewellery shops. The article analyses several Leicester-based businesses’ particular input into the design and manufacture of synthetic saris in this globalised trade, as well as the distribution and consumption of Japanese saris in other contexts. The article concludes with an evaluation of the importance of multiple migrants in the production of Japanese saris and of the implications of this case study for conceptualisations of the reproduction of culture and heritage in diaspora communities.

\section{SARIS, STYLES AND FIBRES}


The sari is the quintessential female garment associated with India, even though it is also a common garment in neighbouring countries, including Nepal, Bangladesh and Sri Lanka and in many countries with large South Asian diaspora communities, where not only those who identify as being of SouthAsian heritage may wear them.

The history of the sari goes back at least two thousand years. The garment as we know it today, in all its variations, developed out of complex historical and cultural environments that differed from region to region. ${ }^{10}$ Saris come in different lengths but what they share in common is that they are a piece of uncut fabric wrapped around the body. The style of draping is influenced by the region, community, caste and class with which the individual identifies, as well as by fashion and personal style. The Sari School in New Delhi has found that there are 108 ways to tie a sari, ${ }^{11}$ but the most familiar, certainly in Leicester, are the Gujarati and nivi ('national', non-regional) styles. In the former, the pallu (end piece) is draped over one shoulder and hangs down the front. The latter, in which the sari length is wrapped in a figure-hugging style, with the pallu worn over one shoulder and down the back, became widespread in the twentieth century as a national, non-regional style, popularised by famous actresses and closely linked with the Indian independence movement (Figure 2). ${ }^{12}$

[Figure 2 here: $1 / 4$ page. Caption:

Mrs Doshi, wearing a sari tied in nivi style, Town Hall Square, Leicester, 1970.

Photograph: courtesy of Mrs Shah.]

That said, the sari was by no means a universal style of clothing in South Asia until the twentieth century and, indeed, many women who choose to wear 'traditional' dress, have other options available to them, such as the trouser suit (salwar kameez) which, while being most closely associated with Muslim and Sikh women in northern India, has become the outfit of choice for many women, particularly young, unmarried women in South Asia and of the South Asian diaspora. ${ }^{13}$ Indeed, the fashionable combination of tunic or dress over leggings or trousers seen in Western fashion contexts over the last decade can arguably be traced - via various cultural influences, including the pyjama suit of the 1930s and the adoption of 'Indian' styles by the hippy movement of the late 1960s - to the salwar kameez. Lisa Trivedi argues that the widespread adoption of the sari as the standard form of dress for many Indian women was a direct result of the swadeshi ('self-sufficiency') movement. Women seeking to signal their commitment to the independence cause often wore the sari for the first time (typically in plain, khadi hand-woven - cloth), as a type of national dress, which, as Trivedi notes, was a departure in dress for many Indian women, who were more used to wearing other forms of clothing. ${ }^{14}$ Gujarati women, for example, had typically worn an outfit comprising a long, flowing skirt and tunic-like blouse (lehanga or ghagra choli), with a scarf (odhnis) wrapped over the head, since, perhaps, the eleventh century BCE. ${ }^{15}$ 
At the time of writing, many women of Gujarati ancestry in Leicester, for example, reserve this style of dress for special occasions, such as events surrounding the festival of Navratri. However, it is important to note that one of our interviewees recounted that during the 1950s and 1960s, prior to migration from East Africa, Asian women of Gujarati ancestry typically wore saris, although they still looked towards Gujarat (and specifically Kutch) as inspiration for the embroidery that adorned their garments. ${ }^{16}$

Bhachu argues that by the mid-twentieth century, the period of most intensive South Asian migration to Britain, the sari had become closely associated with 'upper-class Indians', while the salwar kameez was 'negatively charged'; perceived as being a working-class garment, worn exclusively by Pakistani women. Women who wore salwar kameez often became the targets of racist abuse. ${ }^{17}$ This suggests an alternative motivation for the widespread adoption of the sari among South Asian women migrants to Britain.

The present-day wrapped and draped sari is typically worn over a short-sleeved choli (blouse) that leaves the mid-riff of the wearer exposed, and petticoat, the precedents of which emerged among 'educated urban women and some rural women' by the late nineteenth century. ${ }^{18}$ Sari blouses have been as much subject to fashion as the style and drape of the sari. This can clearly been seen in a collection of choli from the 1960s and 1970s, donated to Leicester Arts and Museum Service in 2011, which feature, amongst other design elements, mandarin collars, long chiffon sleeves, puffed shoulder seams and fashionable colours. ${ }^{19}$ A petticoat is worn under the sari, which, it has been claimed, was first introduced in India under British rule. Many Indian women of the nineteenth and early twentieth century lived in purdah ('seclusion') which removed the need to cover up. It was not until women left this seclusion and emerged into 'polite society' that modesty in dress became a particular issue of concern. ${ }^{20}$ This led, Goswami notes, to the widespread adoption of choli and cotton petticoats with drawstring waists worn under fine and translucent saris. ${ }^{21}$ However, it seems equally likely that the combination of sari, blouse and petticoat is simply a variation on the blouse, skirt and scarf/unstitched cloth worn by many women across India, including Gujarat, before the twentieth century.

Since the twentieth century saris have been made of silk, cotton or manmade fibres. Before the availability of synthetic fabrics, saris were typically made of hand-woven and, in the case of contentious materials imported to India from Britain, machine-made cotton and silk materials. Synthetic fibres - long continuous filaments created from chemicals based on oil or coal residues of which nylon, acrylic and polyester are the best-known - developed in the early twentieth century, although the first artificial fibres, made from wood, had been produced in the mid-nineteenth century. Nylon was patented in 1935 by the Du Pont chemical company and launched in $1938 .^{22}$

The manufacture of silk and cotton textiles exported from Japan to the Indian subcontinent and destined to become sari lengths began as a result of developments in the pre-Second World War sericulture industry. Silk and silk products were a major source of foreign exchange for Japan. ${ }^{23}$ In the 
late 1920s and throughout the 1930s, Japan was also the world's leading textile exporter of cotton cloth. This was challenged by draconian anti-Japanese protectionist policies in the UK and the US, ${ }^{24}$ although by 1952 Japan had once again achieved world dominance in textile exports. ${ }^{25}$ This dominance was threatened by increased cotton cloth manufacture in many other countries and led to diversification into synthetic fibres. Japanese textile exports were in ascendancy once again by the end of the $1950 \mathrm{~s} .{ }^{26}$

As a case in point, Toray Industries was established by Mitsui Group as Toyo Rayon in $1926 .{ }^{27}$ In 1951, Toray was the first Japanese manufacturer to produce Nylon, under licence from Du Pont. Around the same time, Toray and another leading synthetic textile firm, Teijin, introduced polyester fibre production under licence from ICI. ${ }^{28}$ Between 1952 and 1962 synthetic fibre output increased from 54,000 to more than 215,000 tons. By 1965, this figure had risen to 380,000 tons. In 1953 there was only one Japanese manufacturer of Nylon. By 1963, this number had increased to six. ${ }^{29}$

\section{JAPANESE SYNTHETIC SARIS}

The use of synthetic material for saris grew rapidly in the second half of the twentieth century. Interviews with sari shop owners in Leicester and Nairobi confirm that later in the century fabric that was Japanese-made (or East African-made by Japanese-owned mills, making use of Japanese-made yarn) was specifically manufactured and sold with saris in mind. ${ }^{30}$ Prior to this it seems that Japanese synthetics were produced for more generic markets, although this most likely included material which was ultimately cut into sari lengths.

Synthetic saris had clear advantages over their antecedents. They were quick and easy to launder - one source suggests their popularity in India was a direct result of declining numbers of dhobis (launderers) $^{31}$ - and they were shrink and crush resistant. They did not fade over time with washing and drying, they were hard-wearing and durable and suitable for everyday wear. Furthermore, they had a 'silk-look' dressiness, but were inexpensive to buy. ${ }^{32}$ For example, in 1973 the Leicester Mercury reported that in the city’s sari shops, a printed nylon sari cost around $£ 4$, compared with $£ 40$ for a handstitched and beaded red and gold wedding sari. ${ }^{33}$ Synthetic saris were also lighter in weight and sometimes quite transparent. Usha Ben Shah, interviewed in Nairobi in 2010, described wearing 'glass' nylon saris in the 1960s, which were - as the name suggests - see-through 'like glass'. On one occasion, the headmaster of the Kenyan school at which she worked as a teacher sent her home to change out of a particularly translucent yellow glass sari for something more suitable, much to her great annoyance; not least because the incident prompted her mother to say 'I told you!'.34

Priti Mattani, a Kenyan-born sari shop owner of Gujarati heritage, who moved to Britain as a teenager, reminisced that her mother's generation had only worn saris while in East Africa, never 
trousers. On starting factory work in Britain, they were not permitted to wear saris for health and safety reasons:

It would get caught in a machine, so people changed into trousers ... I remember Mum going to work in a pair of trousers and the minute she got home, she had to be back into a sari because that was her comfort zone, but then what she wore in the house would obviously have to be something that she could wash quickly either by hand or put in the machine because that made it easier and she needed it again the next day and it had to be dry. ${ }^{35}$

Changing into a sari at the end of the work day might well have been a matter of comfort for many women. But the situation with regards to saris at work was more nuanced and reflected generational differences among women of South Asian backgrounds in the world of work. And, as Dwyer notes, some women may also have chosen to wear Western clothing at work to avoid racism. ${ }^{36}$ In her feminist study of a large textile factory in Leicester ('Needletown') in the early 1980s, Sallie Westwood recounts an interview with a union rep who described how the older women in the workforce insisted she ask management to allow them to wear saris to work. Westwood identifies this as a desire among the women for 'recognition of their culture and their status as women in the Indian community. They very much disliked wearing Western clothes and most wore trousers with smock-like tops in order to retain their propriety'. ${ }^{37}$ This was refused on health and safety grounds. In any case, the younger women chose not to wear saris - especially those who were married and might have been facing pressure from their husbands to wear a sari at home. ${ }^{38}$ Westwood writes of a factory worker, Taruna, who was made to wear saris by her husband. He also 'tells her where she can go and who she can go with'. Taruna commented:

I came here and went to school, so I always wore English clothes, now I wear saris much more. I used to think they were not nice because you couldn't walk about in them, but my husband likes them. He says it's not nice if someone comes to the house and I am in these clothes [her working clothes]. ${ }^{39}$

This echoes Mukulika Banerjee and Daniel Miller’s findings that many young newly married women in early twenty-first century India, who grew up wearing Western clothing or salwar kameez, find the transition, perhaps under pressure from their husband's family, to wearing the potentially more revealing and unpredictable sari (especially for a novice sari wearer), an uncomfortable experience. ${ }^{40}$ The 'comfort' of changing into a sari at the end of the working day may have had as much to do with maintaining equilibrium at home, as the feel and familiarity of the fabric.

Some synthetic saris may have been produced in Japan (and Korea) as early as the inter-war years, perhaps in the form of material subsequently re-purposed as sari lengths. ${ }^{41}$ The Victoria and Albert Museum collection features a pink, black and silver example manufactured around 1930, stamped 
'Made in Japan' and worn by its Nepalese owner in India. ${ }^{42}$ But it was in the 1970 s that Japanese saris (that is, Japanese manufactured and printed fabric expressly marketed as 'sari') became very popular with the South Asian community for their quality, affordability and contemporary colours and designs, which drew heavily on the Western fashions of the day. ${ }^{43}$ Psychedelic floral prints, polka-dots and stripes were common - although a Japanese aesthetic was occasionally in evidence, as figure 3 demonstrates in its characteristically Japanese floral motif.

[Figure 3 here: 1/4 page. Caption:

Japanese sari stamped on the selvedge with 'Made in Japan' and showing the influence of Japanese aesthetics in its design. c. 1960s-70s. Leicester Arts and Museum Service.Y.E4.2012.1.0.

Photograph: @Leicester Arts and Museum Service.]

Synthetics allowed for sharper printing and high colour saturation, creating 'a totally new look'. ${ }^{44}$ India could not compete. As late as the 1970s, only a few Indian mills had the capability to produce polyester chiffon saris of decent quality, even when they used Japanese-made synthetic yarn. ${ }^{45}$ Garden Silk Mills was the principal exception. As Banerjee and Miller note, Garden's synthetic saris, printed with floral prints and in pastel colours, were advertised widely and became popular with women in India's urban centres. ${ }^{46}$ Like Garden's saris, the up-to-date designs produced in Japan largely abandoned the convention of bordered, banded motifs, favouring all-over patterns instead, mainly as a result of technological issues. At that time, Japanese (and Indian ${ }^{47}$ ) mills did not have the expertise to manufacture synthetic sari lengths with printed pallu, ${ }^{48}$ the end-piece of a tied sari, which was an especially important design feature when worn loose in front (Gujarati style). As a result, Japanese saris lent themselves to being worn in the non-regional nivi, or 'national' style, which had become chic after Indian independence and had been popularised by film stars and celebrities. ${ }^{49}$ The status of the synthetic sari therefore changed radically, or in the words of Banerjee and Miller: 'Through novel design and skilful marketing, the synthetic sari, previously thought of as a hard-wearing economy garment, became an expression of chic and modernity among the middle class'.50

The contrast between the flashy new Japanese synthetic saris and their silk and cotton antecedents is evocatively illustrated by a passage from Anita Desai’s 1984 novel In Custody, which also hints at their fashionable 'edginess' and appeal to 'modern' South Asian women. Describing them as 'lurid' and 'covered in octopi and spiders of flower patterns and nets of gold and silver embroidery', Desai's protagonist views the Japanese nylon saris displayed in the doorways of sari shops in Delhi as 'gaudy but shimmering prostitutes propositioning the passers-by, while the rich soft traditional silks were folded and stacked in sober, matronly bales at the back' ${ }^{51}$ 
To understand the multiple global aspects of Japanese saris beyond the different geographies of production and distribution, we need to focus our attention on South Asian diasporas and their specific migration routes; in particular on those groups who are often referred to as East African Asians. At the time of writing, this heterogeneous community - in terms of social, economic and religious background and of the motivations and migration routes of individuals and generations - has a large presence in Leicester, London, Gujarat and East Africa.

These migration histories are inextricably linked with the tight-knit relationship between industrialisation and British imperialism. Although South Asia and East Africa have been connected through old Indian Ocean trade networks for over 2,500 years, with settlements of people from Western India along the East African coast and in Zanzibar, ${ }^{52}$ large groups of South Asians only migrated to East Africa and other parts of the British Empire in the nineteenth century. In this early period of globalisation between 1870 and 1914, ${ }^{53}$ India was at the heart of this relationship between British colonialism and a new world economic order, as a source of raw materials, a destination for capital and a source of labour for other parts of the Empire. ${ }^{54}$ South Asians, especially those from Gujarat, who migrated to East Africa were not, unlike many Indians who migrated to Trinidad, Guyana, Mauritius, Natal in South Africa, Suriname and Fiji, for example, under a contract of indenture. ${ }^{55}$ Between 1896 and 1901, at least 32,000 people, particularly from the Punjab, moved to East Africa and were contracted to work on the East African Railways. ${ }^{56}$ Although precise numbers are not known, many people from Western India travelled to East Africa as free migrants, partly following long-standing patterns of Indian trade within this region or taking up new opportunities of employment within the British colonial civil service. They were sometimes known as 'passenger Indians' because they paid for their own sea passage and often settled long-term or permanently. ${ }^{57}$ Many stayed as low ranking civil servants, shopkeepers and professionals. Families were brought over, homes and businesses were established, and the Asian community prospered. Until the 1940s, close economic and social contact with South Asia remained, with significant movement within a transnational space from India to eastern Africa. ${ }^{58}$

From the 1960s, in the wake of African independence movements, anti-Asian resentment grew, especially over the perceived economic successes of the South Asian communities. The situation culminated in the 1972 expulsion of Asians from Idi Amin’s Uganda. Many East African Asians - from Uganda, Kenya and Tanzania - typically held British citizenship as a legacy of colonialism and chose or were forced to leave their homes and businesses. People resettled in India, North America and Europe (particularly in the UK). By 1968, 3,000 Kenyan Asians had settled in Leicester. In spite of, or perhaps because of the City Council's campaign to discourage more East African Asians from settling in the city, with the arrival of people from Uganda, Leicester became a key site of migration. ${ }^{59}$ Eventually, around 
28,000 Ugandan Asians settled in Britain, a large proportion in Leicester. They principally found homes, set up businesses and worked in and around the Belgrave Road area, helping to revitalise a part of the city which had been earmarked for demolition and clearance. ${ }^{60}$

In the nineteenth and for much of the twentieth century, Leicester was a prosperous town (and city from 1919). Its wealth was based on manufacturing and light industry, with a particular emphasis on hosiery, knitwear and boots and shoes, and it was known for its large female workforce. ${ }^{61}$ Leicester's industries had long attracted workers from outside the city and county. From the turn of the twentieth century, migrants of Jewish and East European origin settled in the city. After the Second World War, the immigrant population in Leicester grew steadily, including a small number of migrants from India and the West Indies, who helped to mitigate the post-war labour shortage. ${ }^{62}$

Many of the immigrants from East Africa who arrived in the city in the 1970s found employment in Leicester's factories. Women often needed to work in order to supplement the family income. ${ }^{63} \mathrm{~A}$ report commissioned by Leicester City Council in the early 1990s found that many Asian women chose to work in clothing factories where they felt 'comfortable' and could 'talk in their own language', ${ }^{64}$ and where the work was 'the most natural option'; many were experienced seamstresses, even if they had not worked outside the home before coming to the UK. ${ }^{65}$

While workers from the Indian sub-continent began to arrive and to take up employment opportunities in the city's textile industries after the Second World War, sari shops were not established in Leicester until after the migration of East African Asians. There are a number of reasons for this. Firstly, East African Asians intended to settle permanently in the UK. There was no possibility of them returning home in the future and they had few options but to make new lives in Britain. In contrast, people who migrated directly from India often retained family contacts with friends and relatives who could send them, amongst other items, clothes and accessories. Secondly, many of the East African Asians who came to Britain had entrepreneurial skills and capital, as well as experience of setting up and running businesses prior to migration, which helped them to settle very quickly. For example, Mrs Vijyaben Chauhan, founder of Milans, moved to Leicester in the 1960s from East Africa. She started her business because she could not find appropriate clothing for her daughter's wedding. Identifying a gap in the market, she opened her first shop on Hartingdon Road in the Highfields area of the Leicester and a little later, a second branch on Belgrave Road. ${ }^{66}$ Many others followed these early pioneers, helping to meet an increasing demand for saris and synthetic saris more specifically.

It was during this period that the synthetic sari, imported from Japan, became popular among all those who moved or stayed behind, voluntarily or compulsorily, within the transnational space of East Africa, Britain and India. Mr Gutka, the owner of Emerson's, one of the longest-established sari shops in Nairobi, remembered the large numbers of Japanese saris, specifically marketed as such, that were sold to East African Asians in the 1970s. ${ }^{67}$ Indeed, a number of Japanese textile manufacturers worked in 
partnership with several mills in East Africa. The aforementioned Toray, for example, was in business with Kenya Taitex Mills (KTM). ${ }^{68}$ Goods produced in Japan were exported via Kobe and docked at Mombasa. ${ }^{69}$ Due to India's protectionist import policies in the mid- to late twentieth century, many East African Asians took Japanese-manufactured garments in their luggage to India, as gifts for friends and family and to sell on. Mr Gutka reminisced that 'There were people who came from India [to Mombasa] especially to buy those sorts of things' ${ }^{70}$ Several of our interviewees informed us that many East African Asians brought Japanese-made saris with them when they arrived in Britain, suggesting that they were worn in Africa as every-day, practical garments which found a place in Britain because they lent themselves to many East African Asian women's busy new lifestyles. ${ }^{71}$

By the late 1960s synthetic saris were being produced in India, particularly in Surat, Gujarat. It is apparent, therefore, that Japanese saris were not solely valued because they were the only choice of synthetic sari available. In her examination of South Asian women's patterns of clothing production and consumption in Leicester, Parvati Raghuram notes that 'second-order meaning' is a characteristic of diasporic fashion: the place of production is often 'valorized' and contributes to the " "authenticity" ... ascribed to the product precisely because of the location of its production and producers'. ${ }^{72}$ It was specifically because of their superior quality, fashionable designs and restricted availability in India, that Japanese saris became very desirable - those prominently stamped 'Made in Japan' on the selvedge particularly so, and some wearers made sure this was visible ${ }^{73}$ (Figure 3).

\section{LEICESTER'S ROLE}

The exodus of people from East Africa to Britain meant that the focus of the sari business partly moved as well. The new economic position of migrants in places like Leicester, who often had much less leisure time than they had had in East Africa, as well as the growing fashion for synthetic fabrics in the 1970s, further contributed to the expanding market for Japanese saris. Together with London, Leicester played an important role.

Japanese saris suited the new lifestyles of East African Asian migrants. They were thought of as hard-wearing, economy garments and were worn by women who often worked outside the home for the first time in their lives, typically, in Leicester, in textile and food factories. The demand was for less formal, everyday fashionable saris. ${ }^{74}$ Mrs Chauhan of Milans began the business in the late 1960s: the current Belgrave Road shop opened in 1969 in an old sewing machine shop. ${ }^{75}$ Milans continued to sell the remaining stock of sewing machines for some time, alongside household utensils. But the shop's principal business (as it remains today) was saris and from the early 1970s the Belgrave shop concentrated on fashion. ${ }^{76}$ Around seventy per cent of the stock comprised imported Japanese prints for everyday wear, which particularly appealed to the younger generation who were interested in wearing 
Western-influenced designs. The older generation favoured more classic prints from Gujarat and Rajasthan. In general, customers preferred to reserve their hand-woven cottons and silks manufactured in Varanasi (Benares) for parties, weddings and formal events. ${ }^{77}$

Between the late 1960s and 1980s several East African Asian sari shop owners based in Leicester, among them Milans and Sona Rupa, were heavily involved in the design, manufacture, import and sale of synthetic saris made in Japanese factories (Figure 4).

[Figure 4 here: $1 / 4$ page. Caption:

Inside sari shop ‘Sona Rupa’, Belgrave Road, Leicester, 2011.

Photograph: Malika Kraamer.]

Priti Mattani, owner of Sona Rupa, stressed that the business was principally known for high-end, handwoven saris imported from India. Nevertheless, shortly after she joined the business, which had been founded by her husband's parents, the shop began to stock synthetic saris made to Sona Rupa's specifications in Japan. Many of the customers wanted 'something that was wash and wear, easy to look after, easy to iron ... There was a market for that. There was a community [in the UK] that wanted all that'. 78

The sari shops catered to the local community by developing their own fashion-forward designs in partnership with local designers and fashion and textile students, which were then sent on to Japan to be manufactured. One textile designer from India settled in Leicester and was employed by Milans. ${ }^{79}$ These designers took their inspiration from many sources, especially Western fashion trade magazines such as Drapers and followed contemporary global fashion trends: ${ }^{80}$ psychedelic prints, all-over floral designs and spots and stripes were common. In this respect, along with three or four predominantly London-based competitors, Milans were leaders in the Japanese sari trade. ${ }^{81}$ By the late 1970s Milans had employed the well-known Indian actress, Shabana Azmi, to advertise their range of Japanese-made saris, reproducing images from Mumbai (then Bombay) photo-shoots in promotional materials, including posters and calendars. ${ }^{82}$ In addition, Milans pioneered a new-style Japanese sari, a key characteristic of which had previously been the lack of a printed pallu. As previously mentioned, for a period of time, Japanese (and Indian) manufacturers did not have the technical expertise to print saris with pallu, but this changed when in the 1970s Kishor Chauhan of Milans worked with Japanese manufacturers to produce the first Japanese synthetic saris with printed pallu, which allowed them to be worn in a more conventional Gujarati style. ${ }^{83}$

Similarly, Priti Mattani’s family business Sona Rupa pioneered designs with the British-Gujarati market in mind, although as her own comments suggest, this arrangement began around 1985, sometime after Milans’ involvement with Japanese manufacturers: 
we specialised a lot in ... printing our own designs on this Japanese fabric, so before, the Japanese decided the designs. You would just ... choose the designs which [were] available. But then we decided why don't we make it [Japanese fabric] tailor-made to the types of designs that we like ... or the Asian market likes? So we did a lot of work on that, a good twenty years where we innovated different ways of making. ${ }^{84}$

Priti's husband, who operated the wholesale side of the business, worked directly with Japanese manufacturers and supplied sari retailers across Britain, in London, Bradford and Manchester, as well as the family outlet on Belgrave Road to ensure that supply met demand: 'he would maybe come home and say, "You know a lot of people have been asking for green now, is that the fashion colour?" or "Do you find that in the retail side as well? Is there a sudden demand for green, or whatever?” '. That demand was often peculiarly UK-specific and closely tied to the seasons:

there's a lot of connection between what comes into the English fashions in terms of colours ... because ... in England, where we have four different kinds of weathers ... in winter [we wear] a lot of ... blacks and blues ... but our saris don't come in blacks and blues, they always come in these very bright shades, but when we have lived here for about five or ten years ... you think, 'It looks odd, but in the winter [would] you wear it?'. You know, you wear ... a bright colour, it just doesn’t look right. Our way of thinking has changed ... In summer we want to wear a pastel shade, in winter we want to wear this, so that sort of trend has also changed ... saris as well. [We buy] what we like [and] what our customer likes to buy here [in Britain]. ${ }^{85}$

\section{JAPANESE SARIS IN THE GLOBAL DiASPORA}

Although the focus of this article is on Leicester's role in the development of the Japanese sari, the phenomenon was by no means confined to the city. This is a story of the global South Asian diaspora. As previously mentioned, references to Japanese saris are scarce in scholarly literature and appear sporadically in contemporary fiction. A study of Sindhi migration to Britain mentions, for instance, one trader who had made his money importing sari material into Britain via his brother based in Japan, finding a ready market for his goods among the large community of Bangladeshis resident in London. ${ }^{86}$ Falzon reveals that there were historic precedents for this trade route: Sindhi merchants established outposts in Japan towards the end of the nineteenth century, exporting comparatively cheap but superior quality Japanese-made silks to India. ${ }^{87}$

In another publication that explores the migration histories of people of Gujarati heritage in London and New York, one reads about Mahendra, born in Kenya and an elder of the Oswal community in London. In a story reminiscent of the experiences of several of the sari shop pioneers in Leicester, 
Mahendra was involved in a number of transnational businesses. In the 1960s he bought a shop with his brother to sell flowers and vegetables from India and East Africa and curries made in a factory in Uganda. After the expulsion and seizure of family assets, the brothers diversified into saris, importing their materials from Paris, India and Japan. At one point they owned twelve sari shops, although these were later sold as a result of conflict within the family. ${ }^{88}$

In North America too one can find references to Japanese saris. Devon Avenue was established as a centre for Chicago's South Asian community by the 1980s, with the first Indian-owned shops opening in the early 1970s. ${ }^{89}$ The first sari shop in that locale, India Sari Palace, began trading in May 1973, selling - amongst other materials - affordable Japanese synthetics. Interestingly, the family behind this venture had been migrants from India who had first settled in Hong Kong in the 1940 s. $^{90}$ One might assume that their trade relationships with Japanese manufacturers were first established during that period. Indeed, many Sindhi businesses were extant in Hong Kong and other trade hubs during that period. $^{91}$

In the early 1980s there was a distinct shift in the synthetic sari trade. Japanese saris became directly available in India for the first time, because of the lifting of trade restrictions which had previously prohibited imports from Japan: import tariffs were reduced and Indian suppliers started to import directly from Japan. ${ }^{92}$ In addition, by this period, Indian manufacturing technology had advanced to such an extent that Indian synthetic materials rivalled the products of Japanese competitors in quality. ${ }^{93}$ In the 1980s Surat in Gujarat - soon to become home to the 'sari czars ${ }^{94}$ - overtook Japanese production and became established as the global centre of synthetic sari manufacture. ${ }^{95}$ And yet, it was at this time that the vogue for synthetics began to wane. The owners of India Sari Palace on Devon Avenue in Chicago reduced the size of the store as demand for Japanese synthetics fell, opening in its place an 'upscale' restaurant, Tiffin, in $1995 .{ }^{96}$ An insight into one of the key reasons for the Japanese (and synthetic) sari's ultimate fall from favour is provided by an overheard conversation reported by New York Magazine in 1987:

[At the Taj Sari Palace, a 'luxurious' shop on $74^{\text {th }}$ Street, New York] A patrician-looking woman with a Western-style hairdo, a diamond in her nostril and a tweed coat over her sari, is inspecting new fabrics. She remarks to her Indian friend, who’s wearing slacks, 'The Japanese do compliment us with these new designs'. (She is referring to the new computer-made prints from Japan.) The friend replies, in an austere tone, 'Yes, but some are too, too ordinary'. ${ }^{97}$

When the novelty of Japanese saris faded, their ubiquity became 'ordinariness' and the market was flooded with cheaper Indian-made synthetics, fashionable women, perhaps, as Banerjee and Miller note, inspired by Indian Prime Minister Indira Gandhi’s penchant for handwoven cloth and regional styles, ${ }^{98}$ looked elsewhere for up-to-the-minute trends. From the 1980s and increasingly into the 1990s, natural 
fibres were favoured by the aspirational and well-to-do. ${ }^{99}$ Certainly in India and East Africa, the trend for embroidered and embellished cotton saris has seen leading polyester manufacturers diversifying into cotton and newer synthetics like viscose. ${ }^{100}$ In 2015, mass-produced, non-couture synthetics are considered unsophisticated and cheap. A women’s group in Nairobi, interviewed in 2010, described nylon saris as 'flashy' and 'not in', unless they are 'designer'. 101

The largely incidental references recorded here belie the global popularity of the Japanese sari in its heyday. While these mentions of Japanese saris in British and North American South Asian diaspora communities may only provide 'snap-shot' glimpses of a particular temporal moment, they chime with the experiences of Leicester-based businesses and the city’s role in the Japanese sari story.

\section{CONCLUSION}

Leicester - a city with a long industrial heritage of clothing and woven fabric manufacture - is an ideal place for an examination of the global interactions between South Asian and British fashion, the emergence of British Asian styles of clothing and the role of East African Asians in these developments. Our research on the Japanese sari shows that this global phenomenon would not have occurred without the transnational and multi-migrant nature of the South Asian diaspora and the global outlook of Japanese textile production. It is therefore important that when the transnational processes of cultural products are explored, not only the multiple dimensions and multiple inhabitants of the transnational space in which these processes take place are analysed, but also the particular migration routes of key participants or those (previous) generations they identify with are also taken into account.

It is clear that the Japanese sari deserves further investigation. There are many questions to be explored in future research: how the impact of specific social and political contexts in which multiple migration took place, leading to forced and (semi)-voluntary mass migration and sometimes shifts in the social status of migrants (in this case, Africanisation polices in mid-twentieth century East Africa) impacted on aspects of the highly globalised textile and fashion industry. There is also the potential to ask further questions about the globalised nature of fashion, not only because this line of research would add to an understanding of modern-day cities like Leicester, but also because it would contribute to efforts that focus attention on fashion and design developments beyond what is now often presented as the only mainstream fashion world, that of the Western fashion industry, and link this with studies of transnationalism and globalisation in new ways. Furthermore, the phenomenon of Japanese saris poses fundamental questions on the concept of heritage in the making, unmaking and re-imagining of diaspora cultures. Should we conceptualise it beyond geographical boundaries and even beyond the space of an imagined community? The Japanese sari opens the possibility of starting to examine heritage as transnational and globalised in itself, shifting the focus from a particular place - the homeland - to a 
transnational space which might also help understand what makes and constitutes a diaspora community. ${ }^{102}$

\section{ACKNOWLEDGMENTS}

Malika Kraamer worked as lead curator and Amy Jane Barnes as freelance curator on Suits and Saris, in collaboration with youth and community curators. The research that underpins this article would not have been possible without the invaluable contributions of many people. We thank, in particular, Anjani Ghelani, Jaina Mistry, Linda Amess and Natalie Roberts. A large part of this article is based on research undertaken in Leicester and Nairobi between January 2010 and June 2013. Some of the research was supported by Renaissance East Midlands and Leicester Arts and Museums Service, and formed the foundation of the Cultural Olympiad exhibition Suits and Saris.

\section{AMY JANE BARNES}

Amy Jane Barnes completed her PhD in the School of Museum Studies at the University of Leicester (2009) and has a background in Asian art history. Formerly Curatorial Assistant at the Percival David Foundation of Chinese Art, she is currently employed as a Research Associate in the School of Museum Studies at the University of Leicester.

\section{MALIKA KRAAMER}

Malika Kraamer specialises in African and South Asian art, and globalised fashion and textiles. She finished her PhD in African Textiles at SOAS, in 2005 and has taught and worked at universities and museums in Britain and the Netherlands. She currently works as an independent curator and part-time lecturer, and is Curator of World Cultures at Leicester Arts and Museum Service.

\footnotetext{
${ }^{1}$ A legacy of this exhibition, including all the text panels, the audio guide and many images of objects can be found online, at: http://www.storyofleicester.info/exploreleicester/exhibitionarchive/ The 'Stories of the World' museum strand of the Cultural Olympiad was a complex project in both conceptual and organizational terms. In Leicester, the choice was made to create an intergenerational participatory exhibition that sat between social history and fashion, with young people as the main target audience. One of its key messages was that communities are comprised of diverse individuals, while at the same time, similarities in experiences and behaviour can often be found between individuals and groups that identify as belonging to different communities. Rather than being didactic, the exhibition invited visitors to ask questions and discover shared experiences below the surface of perceived differences. Human-interest stories, therefore, formed the main part of the exhibition.

${ }^{2}$ P. Bhachu, Dangerous Designs: Asian Women Fashion the Diaspora Economics (New York and London: Routledge, 2004), pp. 13-14.
} 
${ }^{3}$ C. Breward, R. Crill and P. Crang eds, British Asian Style: Fashion \& Textiles/Past \& Present (London: V\&A, 2010); P. Bhachu, 'It's hip to be Asian: the local and global networks of Asian fashion entrepreneurs in London', in C. Dwyer, P. Jackson and P. Crang eds, Transnational Spaces (Oxford and New York: Routledge, 2004), pp. 40-59; Bhachu, Dangerous Designs; C. Dwyer, 'Tracing transnationalities through commodity culture: a case study of British-South Asian fashion', in Dwyer, Jackson and Crang eds, Transnational Spaces, pp. 60-77; E. Tarlo, Clothing Matters: Dress and Identity in India (Chicago: University of Chicago Press, 1996); E. Tarlo, Visibly Muslim: Fashion, Politics, Faith (Oxford and New York: Berg Publishers, 2010); R. Lewis ed., Modest Fashion: Styling Bodies, Mediating Faith (London and New York: I.B Tauris, 2013).

${ }^{4}$ M.-A. Falzon, Cosmopolitan Connections: The Sindhi Diaspora, 1860-2000 (Leiden: Koninklijke Brill NV, 2004), p. 181; M. V. Poros, Modern Migrations: Gujarati Indian Networks in New York and London (Stanford: Stanford University Press, 2011), p. 77.

${ }^{5}$ See, for example, C. Bannerjee Divakaruni, Arranged Marriage (London: Black Swan, 1997), p. 25 and S. Pradhan, Dancing with Shadows (Bloomington, IN: Partridge India, 2014), p. 86.

${ }^{6}$ See, for example, M. Chand, House of the Sun (London: Faber Finds, 2012), not paginated.

${ }^{7}$ There is a new wealth of scholarship in different academic fields such as anthropology, art history, design and fashion, including articles, monographs, edited volumes and journals. For an overview see K. T. Hansen, 'The world in dress: anthropological perspectives on clothing, fashion, and culture’, Annual Review of Anthropology, XXXII (2004), pp. 369-92 and numerous Berg publications on the subject, including, for example, S. Niessen, A.M. Leshkowich and C. Jones eds. The Globalization of Asian Dress: Re-Orienting Fashion (Oxford and New York: Berg, 2003); A. Goodrum, The National Fabric: Fashion, Britishness, Globalization (Oxford and New York: Berg, 2005); L. W. Rabine, The Global Circulation of African Fashion (Oxford and New York, Berg, 2002).

${ }^{8}$ P. Jackson, P. Crang and C. Dwyer, 'Introduction: the spaces of transnationality', in P. Jackson, P. Crang and C. Dwyer eds, Transnational Spaces (Oxford and New York: Routledge, 2004), pp. 1, 3, 2.

${ }^{9}$ There is evidence to suggest that synthetic cloth (most likely manufactured in Japan) may have been exported to other parts of Africa, but not necessarily for use as saris. This warrants further research.

${ }^{10}$ See M. Banerjee and D. Miller, The Sari (Oxford and New York: Berg Publishers, 2003) and L. Lynton, The Sari: Styles - Patterns - History - Techniques (London: Thames and Hudson, 1995).

11 Ananda Delhi Textile Developments, Sari School, Taanbaan (Online, not dated). Available from: http://www.anandakhadi.com/sari_school.html [Accessed: 8 November 2013].

${ }^{12} \mathrm{R}$. Tu, 'Dressing the nation: Indian cinema costume and the making of a national fashion, 1947-1957', in E. Paulicelli and H. Clark eds, The Fabric of Cultures: Fashion, Identity and Globalization (Abingdon: Routledge, 2008 ), p. 38.

${ }^{13}$ Mukulika Banerjee and Daniel Miller note that 'Traditionally, girls wore saris for the first time when being presented as potential brides during marriage negotiations'. Prior to marriage, girls and young women have a number of clothing options, including frocks, loose maxi dresses, half saris and salwar kameez. Banerjee and Miller, The Sari, pp. 6566.

${ }^{14}$ L. N. Trivedi, Clothing Gandhi's Nation: Homespun and Modern India (Bloomington: Indiana University Press, 2007), pp. 80-81.

15 Tarlo, Clothing Matters, p. 28.

${ }^{16}$ Oral history interview, Tanman Patel, 9 May 2011, Leicester. This and all the oral histories recorded for this research project have been deposited with the East Midlands Oral History Archive (EMOHA).

${ }^{17}$ Bhachu, Dangerous Designs, pp. 142-43.

18 Tarlo, Clothing Matters, p. 28.

${ }^{19}$ A collection of sari blouses dated between c. 1960s-1990s. Leicester Arts and Museum Service, Leicester City Council, Y.E2.2012.0.0.

${ }^{20}$ S. Goswami, 'Tradition in six yards', in Indian Essentials (New Delhi: Penguin Books India, 2010), p. 185.

21 Ibid.

${ }^{22}$ A key motivation for the development of artificial fibres was to imitate the qualities of silk. Rayon, made from cellulose, was patented in 1924. See the Swicofil website for information about the history and development of rayon. Available from: http://www.swicofil.com/products/200viscose.html [Accessed: 6 June 2015].

${ }^{23}$ Y. Shimato, Japan’s Silk Reelers Blazed an Asian Path of Economic Development (Online, not dated). Available from: http://www.chichibu.com/CHICHIBUSILKHISTORY.html [Accessed: 18 April 2011].

${ }^{24}$ A. Glasmeir, J. W. Thompson and A. J. Kays, 'The geography of trade policy: trade regimes \& location decisions in the textile \& apparel complex’, Transactions of the Institute of British Geographers, XXV (1993), 25.

${ }^{25}$ M. Y. Yoshino, 'The multinational spread of Japanese manufacturing investment since World War II', The Business History Review, $48: 3$ (1974), p. 360.

${ }^{26}$ Ibid., p. 361.

${ }^{27}$ D. L. McNamara, Textiles and Industrial Transition in Japan (Ithaca, NY: Cornell University Press, 1995), p. 52.

${ }^{28}$ Yoshino, 'The multinational spread of Japanese manufacturing investment' p. 362.

${ }^{29}$ Ibid., p. 363. 
${ }^{30}$ Oral history interview, Mr Gutka, 18 March 2010, Nairobi; oral history interview, Priti Mattani, 9 September 2010, Leicester; oral history interview, Kishor and Jyoti Chauhan, 3 March 2010, Leicester.

31 A. Weber, 'Evolution of the saree', India Currents, 6 April 1994 . Available from: https://www.indiacurrents.com/articles/1994/04/06/evolution-saree [Accessed: 30 January 2015].

${ }^{32}$ Banerjee and Miller, The Sari, p. 198.

${ }^{33}$ H. McLean, 'Sari', Leicester Mercury, 27 April 1973.

${ }^{34}$ Oral history interview, Usha Ben Shah, 20 March 2010, Nairobi.

${ }^{35}$ Oral history interview, Priti Mattani, 9 September 2010, Leicester. Until 2012 Priti Mattani was Director of 'Sona Rupa' on Belgrave Road, Leicester. At the time of writing, she has scaled down the retail part of the business, but still operated from the nearby wholesale import sari business of the same name.

${ }^{36}$ C. Dwyer, 'From suitcase to showroom: British Asian retail spaces', in Breward, Crill and Crang eds, British Asian Style, p. 150.

${ }^{37}$ S. Westwood, All Day Every Day: Factory and Family in the Making of Women's Lives (London and Sydney: Pluto Press, 1984), p. 77.

38 Ibid.

${ }^{39}$ Ibid., p. 147.

${ }^{40}$ See, for example. 'Mina’s story', in Banerjee and Miller, The Sari, pp. 13-18.

${ }^{41}$ V. Murthy, 'Displaying saris: fashion gallery of the National Museum of Singapore', The Heritage Journal, III (2008), pp. 16-40.

Sari, c.1930, Victoria and Albert Museum, London, IS.55.1998. Available from: http://collections.vam.ac.uk/item/O131178/sari/ [Accessed: 28 June 2014].

${ }^{43}$ Japanese manufacturers were adept at diversifying into new markets. In the late 1960s, for example, Teijin Tetoron was advertising its fabrics in Drum Magazine, published in Ghana, and emphasizing the versatility of its lines when mixed and matched with African textiles. See for example, http://www.flickr.com/photos/koranteng/2430034238/ [accessed 29 June 2014]. According to one commentator, they did not have much success. Koreanteng, Drum Magazine Ghana 1969, (Online, 2008). Available from: http://koranteng.blogspot.co.uk/2008_11_01_archive.html [Accessed: 29 June 2014].

${ }^{44}$ Banerjee and Miller, The Sari, p. 198.

45 Oral history interview, Kishor and Jyoti Chauhan, 3 March 2010, Leicester.

${ }^{46}$ Banerjee and Miller, The Sari, pp. 196-98.

${ }^{47}$ Ibid., p. 198.

${ }^{48}$ Oral history interview, Kishor and Jyoti Chauhan, 3 March 2010, Leicester.

${ }^{49}$ In this style, the pallu is worn over one shoulder and down the back, and is thus a little more body-hugging than other styles.

${ }^{50}$ Banerjee and Miller, The Sari, p. 198. Japanese factories also made Punjabi suits (salwar kameez), which were imported into Britain and, presumably, around the world, wherever large South Asian diaspora communities had settled. See S. K. Rait, Sikh Women in England: Their Religious and Cultural Beliefs and Social Practices (Oakhill: Trentham Books, 2005), p. 68.

${ }^{51}$ A. Desai, In Custody (London: Vintage, 1999, first published 1984), p. 31.

${ }^{52}$ Some of the earliest settlers in Zanzibar were primarily Kutch and Kathiawar. Most of these migrants were labourers, clerks, book-keepers, carpenters, masons and bricklayers. From the middle of the nineteenth century they expanded to the coast and interior of East African and became dominant traders. See C. Markovits, 'South Asian Business in the Empire and Beyond c. 1800-1950', in J. Chatterji and D. Washbrook eds, Routledge Handbook of the South Asian Diaspora (Oxford and New York, Routledge, 2013), p. 72 and G. Oonk, " "We Lost our gift of Expression”: Loss of the Mother Tongue among Indians in East Africa, 1880-2000’, in G. Oonk ed. Global Indian Diasporas: Exploring Trajectories of Migration and Theory (Amsterdam: Amsterdam University Press, 2007), pp. 17; 83-4.

${ }^{53}$ D. Nayyar, Governing Globalization: Issues and Institutions (Oxford: Oxford University Press, 2002$), 7$.

${ }^{54}$ J. M. Brown, Global South Asians: Introducing the Modern Diaspora (Cambridge: Cambridge University Press, 2006), p. 14

55 Ibid., 19.

${ }^{56}$ Ibid., chapter 2.

57 Ibid., 37.

${ }^{58}$ Anon, IIS Co-Sponsors Conference on 'Literature and South Asian Communities of East Africa', The Institute of Ismaili Studies (Online, April 2003). Available from: http://www.iis.ac.uk/view_article.asp?ContentID=101578 [Accessed: 23 August 2013].

${ }^{59}$ In 1972, Leicester 'gained the reputation of the most unwelcoming of all places to the Ugandan Asian refugees'. V. Marett, 'Resettlement of Ugandan Asians in Leicester', Journal Refugee Studies, VI, no. 3 (1993), p. 248. Even though the response of other local authorities, such as Birmingham and Bradford, was the same or even harsher, the fact that Leicester City Council published its advice to not settle there in the 15 September 1975 edition of the Ugandan Argus gave it added notoriety.

${ }^{60}$ Marett, 'Resettlement of Ugandan Asians in Leicester', pp. 248-59. 
${ }^{62}$ L. Harijan, 'New Technology, Management Strategies and Shopfloor Workers: A Study of Textile and Clothing Industries in Leicester with Special Reference to the Position of Ethnic Minorities' (Unpublished PhD, University of Leicester, 1990), p. 14. For information and statistics relating to the various waves of migration to Leicester, see D. WeekesBernard et al. Leicester Migration Stories (London: Runnymede Trust, 2012). http://www.makinghistories.org.uk/uploads/Leicester\%20Migration\%20Stories\%20210x210\%2028pp\%20v6.pdf [Accessed: 9 June 2015.]

63 MORI, 'Asian Women Workers in the Hosiery, Knitwear and Clothing Industries' (Leicester: Leicester City Council, 1993), p. 1.

64 Ibid.

65 Ibid., p. 2.

${ }^{66}$ Oral history interview, Kishor and Jyoti Chauhan, 3 March 2010, Leicester.

${ }^{67}$ Oral history interview, Mr Gutka, 18 March 2010, Nairobi.

${ }^{68}$ Established in 1965 at Thika, KTM was initially known as Kenya Toray Mills. See R.T Ogonda, 'Kenya’s Industrial Progress in the Post-Independence Era', in W. R. Ochieng and R. M. Maxon eds, Economic History of Kenya (Nairobi: East African Educational Publishers, 1992), p. 299.

${ }^{69}$ Oral history interview, Mr Gutka, 18 March 2010, Nairobi.

${ }^{70}$ Ibid. Priti Mattani made a similar point. Oral history interview, Priti Mattani, 9 September 2010, Leicester.

${ }^{71}$ Oral history interview, Priti Mattani and Vasu Patel, 15 November 2010, Leicester.

${ }^{72}$ P. Raghuram, 'Fashioning the South Asian diaspora: production and consumption tales', in N. Puwar and P. Raghuram eds, South Asian Women in the Diaspora (Oxford: Berg, 2003), p. 78.

${ }^{73}$ Oral history interview, Priti Mattani, 27 January 2011, Leicester. Malika Kraamer discusses a similar practice of prominently showing the stamp featuring country of manufacture (for example, 'REAL DUTCH WAX'), associated with Dutch and English wax-resist fabric consumed and worn in Ghana. M. Kraamer, 'Ghanaian fashion and the interplay between African and national notions of heritage' (forthcoming).

${ }^{74}$ Oral history interview, Kishor and Jyoti Chauhan, 3 March 2010, Leicester; Oral history interview, Priti Mattani, 9 September 2010, Leicester. Kishor noted that East African Asian women considered themselves to be 'a lot more fashionable' and experimental than their more 'traditionally minded' Indian counterparts.

${ }^{75}$ In the late 1970s and early 1980s Milans expanded their sari business into Birmingham, London and Manchester, but today only the Belgrave Road shop continues to trade under the Milans name. Oral history interview, Kishor and Jyoti Chauhan, 3 March 2010, Leicester.

${ }^{76}$ BBC Leicester News, Reflecting on First Sari Shop in Belgrave, Leicester (Online, 17 December 2010). Available from: http://news.bbc.co.uk/local/leicester/hi/people_and_places/history/newsid_9290000/9290940.stm [Accessed: 23 July 2013]; Oral history interview, Kishor and Jyoti Chauhan, 3 March 2010, Leicester.

${ }^{77}$ Oral history interview, Kishor and Jyoti Chauhan, 3 March 2010, Leicester.

${ }^{78}$ Oral history interview, Priti Mattani, 9 September 2010, Leicester. Mattani joined the business in 1984.

${ }^{79}$ Oral history interview, Kishor and Jyoti Chauhan, 3 March 2010, Leicester.

${ }^{80}$ Ibid.

${ }^{81}$ Ibid.

82 Ibid.

83 Ibid.

${ }^{84}$ Oral history interview, Priti Mattani, 26 May 2011, Leicester.

${ }^{85}$ Oral history interview, Priti Mattani, 9 September 2010, Leicester. Similar comments, with reference to the impact of seasonal weather on fashion and colour choice, were made by a group of Asian women interviewed in Nairobi. Oral history interview, Nairobi Asian Women's Group, 18 March 2010, Nairobi: 'England is ruled by the weather. When winter comes you start wearing the navy blue and the browns and the blacks and then the pants become tighter because you don't want the air to go in and all that. When summer comes, you have those linen pants, but here I think that "all year round" is what you want to wear'.

${ }^{86}$ Falzon, Cosmopolitan Connections, p. 181.

${ }^{87}$ Ibid., p. 134.

${ }^{88}$ Poros, Modern Migrations, p. 77.

${ }^{89}$ Indo-American Center, Asian Indians of Chicago (Chicago: Arcadia Publishing, 2003), p. 57.

${ }^{90}$ Ibid., p. 58.

${ }^{91}$ Falzon, Cosmopolitan Connections, p. 121.

${ }^{92}$ Oral history interview, Kishor and Jyoti Chauhan, 3 March 2010, Leicester.

93 Ibid.

${ }^{94}$ V. Razdan, Vintage Indian Saree Ad featuring Persis Khambatta, At the Edge (Online, 2008). Available from: http://8ate.blogspot.com/2008/08/vintage-indian-saree-ad.html [Accessed: 23 July 2013]. 
${ }^{95}$ Oral history interview, Kishor and Jyoti Chauhan, 3 March 2010, Leicester, According to Kishor Chauhan, in 2010 Milans was importing between eighty and ninety per cent of synthetics from Surat: 'It's a very similar sari [to the Japanese synthetic sari]'.

${ }_{96}^{96}$ Indo-American Center, Asian Indians of Chicago, p. 58.

${ }^{97}$ Anon., 'Jackson Heights: the sari strip', New York Magazine, 4 May 1987, p. 49.

${ }^{98}$ Banerjee and Miller, The Sari, p. 198.

99 G. Ramnarayan, An elitist symbol?, The Hindu Folio (Online, 20 June 1999). Available from: http://www.hindu.com/folio/fo9906/99060280.htm [Accessed: 23 July 2013]; Banerjee and Miller, The Sari, p. 198.

${ }^{100}$ M. Sally, Synthetic Fabric Gives Way to Cotton Trends as the Most Preferred Fabric, The Economic Times (Online, 2 June 2011). Available from: http://articles.economictimes.indiatimes.com/2011-06-02/news/29612953_1 fabricdress-material-cotton [Accessed: 23 July 2013]; Oral history interview, Priti Mattani, 9 September 2010, Leicester. It should be noted, however, that an understanding about the qualities of different materials, their look and feel, may have been partially lost as a result of the ubiquity of synthetics over the last forty to fifty years. In 2010 Jyoti Chauhan commented that young women (referring to their clientele in Leicester) were often unable to tell the difference between pure silk and a synthetic material: 'I feel girls today have no knowledge and are completely unaware'. Oral history interview, Kishor and Jyoti Chauhan, 3 March 2010, Leicester.

${ }^{101}$ Oral history interview, Nairobi Asian Women’s Group, 18 March 2010, Nairobi.

${ }^{102}$ A. J. Barnes and M. Kraamer, Title to be confirmed. In S. Watson, A.J. Barnes and K. Bunning eds, Leicester Reader in Heritage and Interpretation (London: Routledge, forthcoming), will explore the implications of the Japanese sari on the concept of heritage in relation to diaspora cultures in greater depth. 